\title{
Disenfranchisement as a Tool of Class War
}

\author{
V. A. Parkhomov ${ }^{1} \&$ P. V. Kurguzov ${ }^{2}$ \\ ${ }^{1}$ Baikal State University, Irkutsk, Russia \\ ${ }^{2}$ East-Siberian State University of Technologies and Administration, Ulan-Ude, Russia \\ Correspondence: Parkhomov Vladimir, Baikal State University, 664003 Irkutsk, Lenin Street 11, Russia. E-mail: \\ pekines-41@mail.ru
}

Received: April 4, 2019

Accepted: April 28, 2019

Online Published: July 5, 2019

doi:10.5539/ach.v11n2p50

URL: https://doi.org/10.5539/ach.v11n2p50

\begin{abstract}
This work explores the issue of disenfranchisement for Soviet citizens during 1926-1931 Troitskosavsk Municipal Soviet (council) Election campaigns and is based on archival data and various election authority reports. It has been shown that disenfranchisement could be used as one of the tools to fight against citizens of bourgeois views and create the New Soviet Society.
\end{abstract}

Keywords: Election Law, Right to Vote, Disenfranchisement, Non-Voters, Election Rights, Restoring Subjective Voting Rights

\section{Introduction}

Subjectively, each and any citizen of at least 18 years of age shall have the right to vote and exercise this right at will. Eligibility to vote and the fundamental principles of this right are established in Russia mainly through the State Constitution, which shall guarantee that the state subjects (citizens) participate in state government and shall be "the supreme direct expression of the power of the people" (Constitution of the Russian Federation, 1993), who shall express their power by taking part in formation of elected bodies of state government, local self-government, and referendums. Throughout the world, disenfranchising criminal convicts is a common practice. Russian election laws also contain a provision establishing that citizens who were previously (or are currently) convicted or serving time in prison may be disenfranchised.

Currently, elections in Russia are governed by the Constitution of the Russian Federation from 1993 year, art. 1 and 3, and are democratic. The term 'democratic elections' is used in a sense that citizens are free to exercise their rights at will. Election authority reports on voting turnout at the President Elections and the State Duma Elections indicate that the elections in contemporary Russia are democratic. The RF President Elections 2012 had the voting turnout of $65.34 \%$, while the same indicator for elections that took place on 18 March 2018 reached $67.47 \%$ (Elective Commission Reports). Voting turnout for State Duma elections was as high as $47.62 \%$ in $2003,63.78 \%$ in $2007,60.21 \%$ in 2011, and $47.88 \%$ in 2016 (Elective Commission Reports). The voting turnout results indicate that the elections were the actual unrestricted expression of power of Russian people. But was it always the case?

\section{Literature Review: History of Election during First Period of Soviet Power}

In 1918-1936 Russian Soviet Federative Socialist Republic (RSFSR), voting rights were governed by the Constitution adopted on 10 June 1918 that has Section 4 establishing the principles of active and passive suffrage (voting rights) (Constitution of the RSFSR 1918). First of all, Chapter 13 of this Constitution contains a detailed list specifying who shall have and who shall not have voting rights. However, the legal procedures for disenfranchising and restoring voting rights were not duly established in the state and all the regions until 1920s. Disenfranchising was used as a tool of the class war in the Soviet Russia from 1918, when the First Constitution of 1918 was adopted, to 1936, when the so-called Stalin's Constitution entered force.

We are not going to cover all the social and demographic parameters of municipal and rural non-voters in the Buryat-Mongolian Republic. However, we do mean to consider how Chapter 4 of the Constitution was used against particular individuals in the Troitskosavsk - Buryat-Mongolian Autonomous Soviet Socialist Republic (BMASSR) during 1928 elections. To clarify our further statements, we will quote the provisions of Chapter 13 Clause 65: 
"The following persons shall enjoy neither the right to vote nor the right to be voted for, even though they belong to one of the categories enumerated above, namely:

(a) Persons who employ hired labor in order to obtain form it an increase in profits;

(b) Persons who have an income without doing any work, such as interest from capital, receipts from property, etc.;

(c) Private merchants, trade and commercial brokers;

(d) Monks and clergy of all denominations;

(e) Employees and agents of the former police, the gendarme corps, and the Okhrana (Czar's secret service), also members of the former reigning dynasty;

(f) Persons who have in legal form been declared demented or mentally deficient, and also persons under guardianship;

(g) Persons who have been deprived by a Soviet of their rights of citizenship because of selfish or dishonorable offenses, for the period fixed by the sentence."

A similar list of persons to be disenfranchised existed in the RSFSR Constitution of 1925 года, Art. 69 (Constitution of the RSFSR, 1925).

The number of such non-voters was substantial and varied region to region. For example, the RSFSR Western Region alone had the increase in non-voters from 1040 thousand in 1927 to 3038 thousand during 1925-1926 campaign (Valuev, 2003).

There were 2433390 disenfranchised non-voters, or $4.5 \%$ of the adult population, in RSFSR. In 1925, the number of rural non-voters amounted to 1706025 citizens (3.9\%), as compared to 1390747 citizens (3.3\%) during 1926-1927 campaign. The percent of the non-voters surged almost everywhere (Soviet Elections and Structure of USSR Government, 1931).

The overall number of non-voters throughout the USSR increased by 700 thousand. As a result, 3716 thousand people ( $4.9 \%$ of the adult population) were disenfranchised. $4.1 \%$ of rural population were made non-voters (Results of RSFSR Elections to Soviets 1929).

Article 15 of Instruction for City and Rural Soviet (council) Elections and Convocating Soviet Congress dated 26 November 1926 (Instruction for City and Rural Soviet (council) Elections, 1926) established the social groups to be disenfranchised and the potential procedure for restoring the voting rights to previously disenfranchised people 'currently engaging in socially useful productive work, provided they prove themselves loyal to the Soviet Regime.' The non-voters had a right to appeal against the resolution of the Electoral Commissions within one week upon the List of the Disenfranchised is published or acknowledged.

\section{Analysis: Elections in Provincial City Troitskosavsk during 1926-1931 Years}

The documents 1-3 show that some of the citizens disenfranchised under Electoral Commission resolutions did appeal to higher commissions with some appeals even answered favorably. As for Troitskosavsk, disenfranchisement was imposed on all ex-officers of the Tsar's Army, including both those that had taken part in the Civil War among the White and those who had had no part in the War at all, and also officers' wives, in addition to the citizens falling under the categories present in the mentioned list established by the Constitution. Disenfranchisement Decrees were based on lists provided by the Municipal Court, Aimak Executive Committee Administrative Department, or party cell data.

The Municipal Court provided the Electoral Commission with 2 lists. The first list contained surnames of the citizens disenfranchised by court judgment for 2-5 years (1926-3, 1927-7 and 1928-6 citizens). The second list consisted of surnames of ex-officers, military officials, policemen (also provided below as Table 1). The Aimak Executive Committee sent a list of 9 priests. The town had several party cell election districts established. The lists written by party cells had a substantial number of citizens included (156) and very peculiar descriptions of the lifestyles and political activities that became the reason to include them. 'An obvious ideological backslider, speculator, ex-speculator, reseller, merchant, black market dealer, related to merchants, worker at a butcher shop, jeweler's wife, ex-tradeswoman, $2^{\text {nd }}$ level school teacher, major tradeswoman, meat seller's husband, caregiver for dependants, drayman, transports people by drought horse, beerhouse host, cattle buyer, visits nomad camps, involved with Harbin due to being active participants of Ungern and Semenov's bands, enthusiastic white bandit, involved in bringing Chinese troops across our borders, communicates with brother living in Manchuria, socialist revolutionary, unemployed, has a priest brother, ex-officer, socialist revolutionary distributing 
propaganda for elections, arrested in 1924 for counter-revolutionary correspondence, former Socialist Revolutionaries party member.'

Here is an impressive excerpt from the last list (National Archive of Republic of Buryatia (NARB), sheet 17, 17 backside). 'Minister Malyshev, Sosnina Street. A priest. Wife of Minister Malyshev, Sosnina Street. Have profits from house holding. Aunt Grunya, Serova Street. Sells beer, kwas, ravioli, uses waged labor. (bold italics by the author). Rychkova, Naberezhnaya Street. Builder working for a border detachment.'

Let us look into the list of the disenfranchised for the Soviets Elections of 1928 provided by the Municipal Court (NARB, sheet 21), the republican Electoral Commission resolution to disenfranchise Barozzi de Els, I.N. (NARB, sheet 9), and an appeal by the wife of ex-Ataman (headman) of the Third Military Unit of the Transbaikal Cossack Army to restore her voting rights (NARB 9, sheet 2, 3).

Table 1. Ex-officers of the White Army living in Troitskosavsk (Resolution: to Electoral Commission)

\begin{tabular}{|c|c|c|}
\hline No. & Full Name (surname, name, patronymic) & Social Position and Rank \\
\hline 1 & Korobin, Sergei Sergeevich & a war-time official \\
\hline 2 & Lizunov, Nikolai Ustinovich & lieutenant of the Semyonov's Army \\
\hline 3 & Lesanobskiy, Kazimir Vikentevich & warrant officer of the Old Army \\
\hline 4 & Kanter, Oleg Pavlovich & warrant officer of the Semyonovich's Army \\
\hline 5 & Kokovin, Leonid Mikhailovich & junker of the Old Army \\
\hline 6 & Kokorin, Pantleimon Semyonovich & junker of the Kolchak's Army \\
\hline 7 & Izhboldin, Dmitri Aleksandrovich & war-time official \\
\hline 8 & Zarubin, Innokentiy Dmitirievich & lieutenant of the Semyonov's Army \\
\hline 9 & Buinovskiy, Mikhail Nikolaevich & sub-lieutenant of the Kolchak's Army \\
\hline 10 & Bobrov, Aleksandr Semyonovich & warrant officer of the Semyonovich's Army \\
\hline 11 & Burin, Pyotr Petrovich & lieutenant colonel of the Old Army \\
\hline 12 & Nikiporenko, Konstantin Semyonovich & official of the war time and the Semyonov's Army \\
\hline 13 & Baranovich, Eugeni Vladimirovich & staff captain of the Semyonov's Army \\
\hline 14 & Khalturin, Semyon Aleksandrovich & Semyonovich Army warrant officer \\
\hline 15 & Pravoverov, Aleksander Vasilievich & Kolchak Army warrant officer \\
\hline 16 & Yakimov, Georgi Dmitrievich & official of the war time and the Semyonov's Army \\
\hline 17 & Lozakovich, Sergei Dmitrievich & official of the war time and the Semyonov's Army \\
\hline 18 & Anisimov, Innokentiy Nikolaevich & sub-lieutenant of the Semyonov's Army \\
\hline 19 & Chirkov, Mikhail Nikolaevich & sub-lieutenant of the Semyonov's Army \\
\hline 20 & Dyomkin, Georgi Stepanovich & official of the war time and the Semyonov's Army \\
\hline 21 & Samoilov, Mikhail Vasilievich & official of the war time and the Semyonov's Army \\
\hline 22 & Overin, Ivan Afansievich & official of the war time and the Semyonov's Army \\
\hline 23 & Buinovskiy, Nikolai Yulianovich & Kolchak Army Colonel \\
\hline 24 & Barozzi de Els, Ivan Nikolaevich & Old Army Colonel \\
\hline 25 & Nikolaev, Pavel Vasilievich & sub-lieutenant of the Semyonov's Army \\
\hline 26 & Berg, Vasiliy Germanovich & Kolchak Army warrant officer \\
\hline 27 & Lisetskiy, Nikolai Anisimovich & sub-lieutenant of the Semyonov's Army \\
\hline 28 & Chirkov, Iosif & sub-lieutenant of the Semyonov's Army \\
\hline
\end{tabular}

After that, a list of former police officers follows, including 2 bailiffs and 4 policemen (NARB 9, sheet 21).

Table 1 includes 6 officers of various ranks and military officials who did not take part in the Civil War with the White Army but were still added to the non-voter list. Among the mentioned officers who did not serve in the White Army, No. 24 is Barozzi de Els, Ivan Nikolaevich.

You can find his service record from the Razvedchik Journal (Razvedchik, 1915), which was being published up to 1917 in St. Petersburg, below (Figure 1). As can be seen in Figure 1, the last date there is 01.08.1916. During the period, Ivan Nikolaevich served as the Ataman (headman) of the Third Military Unit of the Transbaikal Cossack Army. He retired due to health issues on 15 April 1917 (under Order No. 334). He took no part in the Civil War neither with the White Army, nor with the Red Army. His and his son's life are described in (Parkhomov, Barottsi, 2011).

As can be seen (Figure 1), Ivan Nikolaevich made his contribution, had merits to the Country and was faithful in 
his duty in the Old Army. None of paragraphs in Chapter 65 Article 13 of the RSFSR Constitution applied to him.

In addition to the ataman's personal record, he had three sons who served in the Pre-Revolutionary Army and took part in the Great War. One of them, lieutenant Nikolai, died a heroic death at the Western Front in 1916 and was posthumously awarded IV degree Saint George's Cross. Another son also served at the Western Front also was awarded the Order of St. Stanislav IV degree and St. Anne IV and III degree and returned to Troitskosavsk in 1918 for his leave (Parkhomov, 2018).

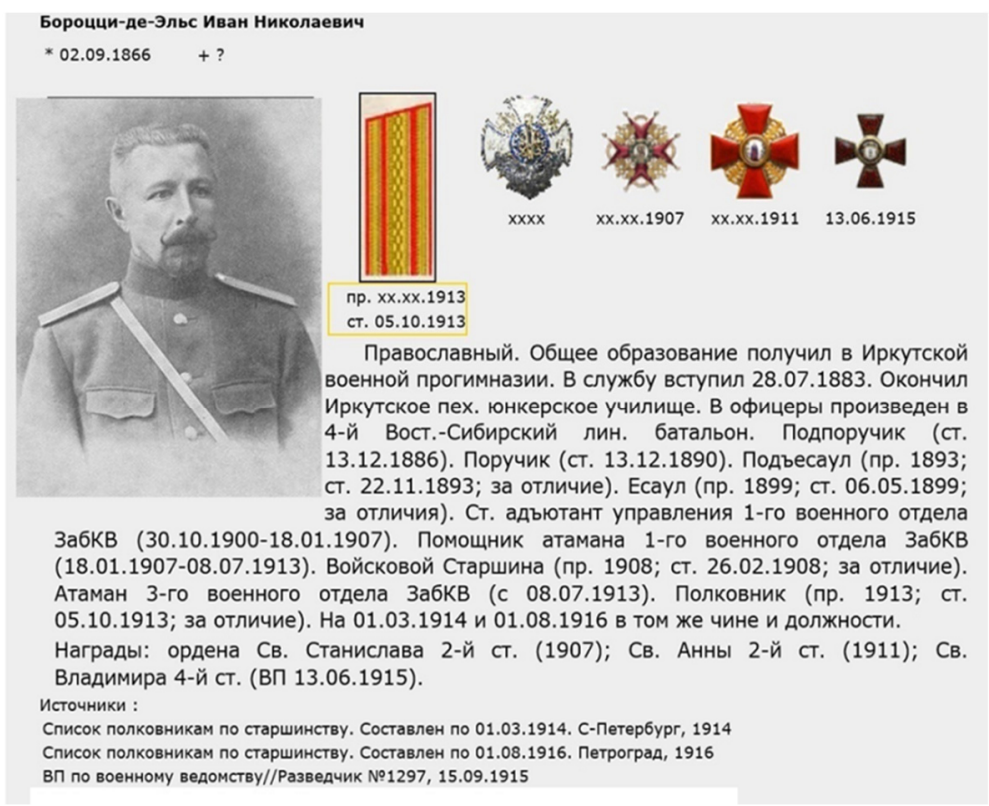

Figure 1. Service record of Barozzi de Els, I.N. from the Razvedchik Journal, 1915. Orthodox. Basic education in the Irkutsk Military Progymnasium. In service since 28.07.1883. Graduated from the Irkutsk Infantry Military

School. Made an officer in the IV-th East Siberian Lineal Squadron. Sub-lieutenant (since 13.12.1886). Lieutenant (since 13.12.1890). Sub-esaul (about 1893, awarded on 22.11.1893 for a merit). Esaul (1899, awarded 06.05.1899 for merits). Senior Aide-de-Camp in the Office of the First Military Unit of the Transbaikal Cossack

Army (30.10.1900-18.01.1907). Assistant Ataman of the First Military Unit of the Transbaikal Cossack Army (18.01.1907-08.07.1913). Lieutenant Colonel (1908, 26.02.1908 for a merit). Ataman of the Third Military Unit of the Transbaikal Cossack Army (since 08.07.1913). Colonel (1913, 05.10.1913 for a merit). As of 01.03.1914 and 01.08.1916, the title and rank remain unchanged. Awards: II Degree St. Stanislav (1907), II Degree St. Anna, IV Degree St. Vladimir (Supreme Order of 13.06.1915).

Sources: Colonels listed in order of precedence. The list established as of 01.03.1914. St. Petersburg, 1914; Colonels listed in order of precedence. The list established as of 01.08.1916. St. Petersburg, 1916; Supreme Orders of the Military Department//Razvedchik No.1297, 15.09.1915

In our opinion, Ivan Nikolaevich was disenfranchised due to the general extrajudicial and class-based approach of the decision-makers. He was considered a person not loyal to the Soviets and a citizen without any employment record after the Revolution. This point of view is supported by the following document 1 drawn up by the BM ASSR Central Electoral Commission that was to reconsider the decision of the Municipal Electoral Commission (NARB, sheet 6).

\section{Document 1.}

«Troitskosavsk

Meeting of the Troitskosavsk Municipal Electoral Commission

Held on 8 January 1931

Agenda: Letter of Request of the Central Electoral Commission dated 9.11. No. 109-b to reconsider if Barozzi-de-Els is to be disenfranchised.

Resolved as follows: Having considered all the materials in the Barozzi-de-Els Disenfranchisement Case, we 
found that: as per art. 15, the citizen in question shall be denied the right to vote as a former Cossack Ataman who have showed no loyalty to the Soviet Rule during all the period thereafter and has no employment record for the period of revolution.

This copy shall deem true and duly signed.

I certify this a true copy. Popova, Secritary.

BM ASSR Central Electoral Commission.

Your Ref.No. Od -1019 dated 23.12.1929.

Our Ref.No. 294 dated 31.12. this year

Please find materials in the Barozzi-de-Els Disenfranchisement Case attached, namely: appeal, exempt from the Aimak Electoral Commission protocol. In addition, Mr. Barozzi-de-Els received exempt from the BM ASSR Central Electoral Commission protocol, where his request to restore him in his right to vote is also denied.

Attachment: as described above.

Zharkoi, Municipal Soviet Deputy Chairman.

Kopylevich, Secretary.

As of now, Ivan Nikolaevich Barozzi-de-Els is a supported by his son, Ponteleimon Ivanovich Barozzi-de-Els, who works for the Troitskosavsk Cooperative Society as an accountant.

Likhonin, Municipal Soviet Chairman.

Popova, Secretary.'

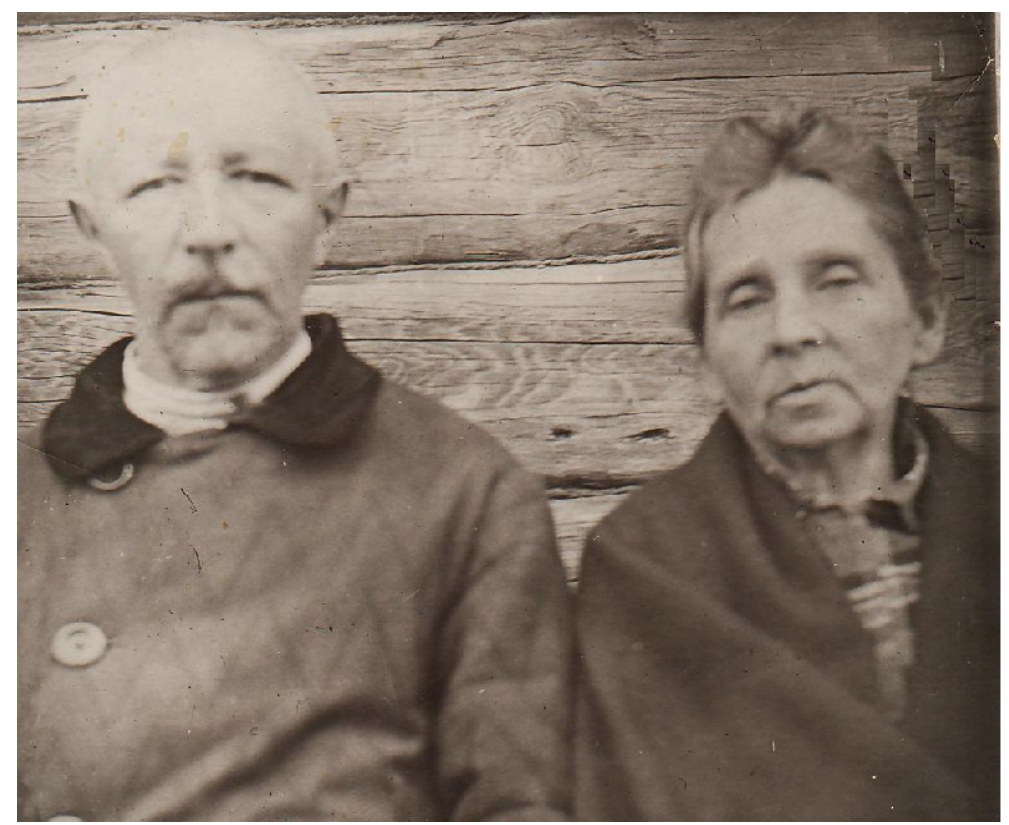

Figure 2. No-voters. Retired Colonel and Ataman of the Third Military Unit of the Transbaikal Cossack Army Ivan Nikolaevich Barozzi de Els with his wife Antonina Klavdievna. (Troitskosavsk 1929 ?)

It is astonishing and respect-inspiring that his wife decided to try and appeal the resolution of the Electoral Commission concerning her voting rights. Her appeal strikes you as an extremely well-formulated writing in term of both Russian language and law (NARB, sheet 2, 3, see Document 2, Document 3 below).

\section{Document 2.}

“To: Troitskosavsk Municipal Soviet Electoral Commission.

From: Citizen Antonina Klavdievna Barozzi-De-Els.

Appeal.

The Disenfranchisement List for the Municipal Soviet Elections published by the Commission had my name listed on account of me being a wife of a former ataman. However, paragraph II art. 12 of the Instruction for 
Soviet Elections adopted by the SSR Central Executive Committee Presidium of 28 September 1926, which is in effect during elections to date, state that 'family members of those disenfranchised shall not be disenfranchised, unless they are dependants of those disenfranchised.' I am not my husband's dependant, as he is disabled, and we both are our son's dependants, which is the reason why I have never been disenfranchised before this year.

Due to the fact that my disenfranchisement has no standing in the Soviet Law, I find it unjust and hereby appeal to restore my civil rights.

Please inform me of subsequent resolution by sending it to my residential address: Troitskosavsk, 1 Ispolkomskaya Street.

22 December 1928.

A. Barozzi-De-Els.”

The Municipal Electoral Commission considered the appeal and resolved it favorably (See Document 3).

\section{Document 3.}

"Troitskosavsk.

Troitskosavsk Electoral Commission.

Antonina Klavdievna Barozzi-De-Els Disenfranchisement Case.

Start Date1928. End Date 1928.

Appeal by Citizen Antonina Klavdievna Barozzi-De-Els.

Exempt from Scheduled Meeting Protocol No.3 of Troitskosavsk Electoral Commission.

Held on 24 December 1928.

Agenda: 6. Appeal by Citizen Barozzi-De-Els, A.K. to restore her right to vote. Nazimov.

Due to the fact that Antonina Barozzi-De-Els is not materially dependent on her husband, who is a former ataman, Ivan Nikolaevich Barozzi-De-Els, and is her son's dependant instead, we find it legitimate to restore the voting rights of Antonina Klavdievna Barozzi-De-Els" (NARB, sheet 24).

\section{Comparison of Electoral Systems in Russia and Australia}

We could conclude the analysis of disenfranchisement as a tool to fight unwanted social layers in the USSR and Russia here. However, we found a way to compare elections through the part citizens of the same surname took in it in the USSR with foreign practice in addition to comparison with the modern-day Russia.

Ivan Nikolaevich and Antonina Klavdievna had a son, Vsevolod, who took part in the Civil War with the White Army of Ataman Semyonov. After the Army was defeated he emigrated to Manchuria with his wife Elizaveta Yakovlevna. They had a son there whom they named Or. After his father died in Harbin, Or with all his family (mother, wife, son and daughter) emigrated to Australia (Parkhomov, 2018). They moved several times and ended up in Paramatta where in 1960 they became Australian Citizens and were included in the Paramatta Electoral Rolls (Figure 3). Thus having lived 8 years in Australia before obtaining the right to vote in the next State Elections in 1962 and Federal Elections in 1963.

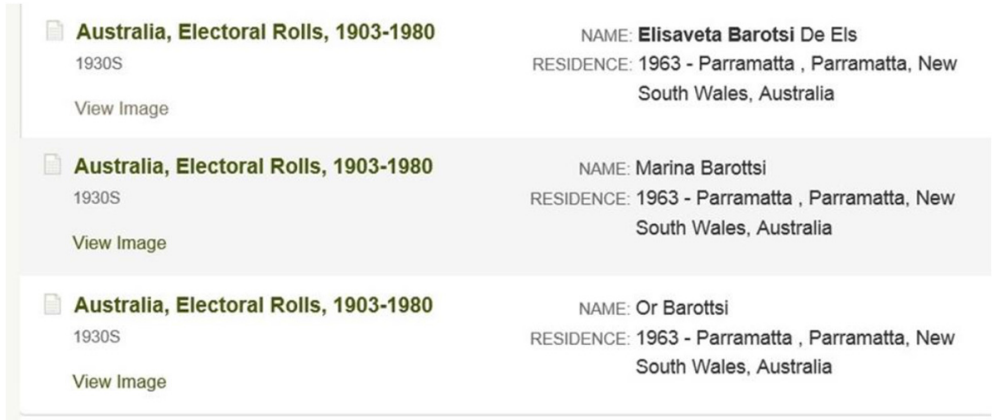

Figure 3. Paramatta Electoral Rolls (Australia)

Australian election system should also be mentioned. Unlike the Soviet Union and Russia where citizens could be deprived of their right to vote, Australia has compulsory voting system. Voting is compulsory at federal elections, 
as well as State and Territory elections. It became compulsory in 1922. This law was introduced due to low voting turnout during federal elections (59.38\%), which meant that the parliament elected could not be considered legitimate. (Compare to turnout of 47.62\% in 2003 and 47.99\% in 2016 for the State Duma Elections in Russia). Australia enforces compulsory voting. People in this situation are asked to explain their failure to vote. If no satisfactory reason is provided (for example, illness or religious prohibition), a fine (ranging from 20.00 to 70.00 $\$ A U)$ is imposed, and failure to pay the fine within specified period may result in a court hearing and additional penalty (Electoral system of Australia).

\section{Conclusion}

In the light of the above data, it can be concluded that disenfranchisement in this individual town, as well as in the USSR in general, was based on the family and social background without taking into account biography, merits and current status of a non-voter. Disenfranchisement was one of the main tools used by the Soviet Government to fight against citizens of bourgeois views and change the social structure by implementing the Policy to Eliminate the Class of Kulaks (Ergina, 2011). However, statistic data provided above shows that disenfranchisement was $4.1 \%$ in rural areas of the USSR and 3.9\% in rural areas of the RSFSR, which means that non-voters were mostly from the well-educated urban population: former officers, officials and small-scale manufacturers.

To sum it up, electoral law in post - Soviet Russia and a country of well-developed democracy is quite different from the Soviet one. Several generations of one family name had to learn this difference the hard way.

\section{Acknowledgments}

We would like to thank Barottsi Elizaveta (Russia) and Connie Barottsi de Els (Australia) for their family archive and in preparing of the paper. We would also like to thank Sophia Asner for translation services.

\section{Conflict of interests}

The authors declare that there is no conflict of interests regarding the publication of this paper.

\section{References}

All-Russian Central Executive Committee. Instruction for City and Rural Soviet (council) Elections and Convocating Soviet Congress. (1926, November 26). Retrieved from http://www.memorial.krsk.ru/DOKUMENT/USSR/301020.htm

Bulletin of All-Russian and USSR Central Executive Committees (No. 118). (1925, May 26).

Code of Justice by the Workers' and Peasants' Government of the USSR (No. 30, art. 218). (1925).

Constitution of the RSFSR. (1918). Retrieved from http://www.hist.msu.ru/ER/Etext/cnst1918.htm

Constitution of the RSFSR. (1925). Retrieved from http://www.rusconstitution.ru/library/constitution/articles/932/

Constitution of the Russian Federation (1993). Moscow: Prospekt, 47.

Elective Commission Reports on Voting Turnouts for Presidential Elections and State Duma Elections 2003, 2007, 2011, 2016. Retrieved from https://www.rbc.ru/politics/08/12/2003/5703b5c09a7947783a5a4e80; http://cikrf.ru/activity/relevant/detail/29886/; http://cikrf.ru/activity/docs/postanovleniya/26549/; https://tass.ru/info/4844712

Electoral system of Australia. Retrieved from https://en.wikipedia.org/wiki/Electoral_system_of_Australia

Ergina, N. M. (2011) Disenfranchisement in national regions of Volga River Basin during Soviet Elections Campaign of 1928-1929 (evidence from rural areas of Mordovia and Tatarstan). Altai State University Bulletin, 4(1), 88

Parkhomov, V. A. (2014). Family Contract of a Transbaikal Cossack Army Ataman During the Great War. Bulletin of Ancient Technology Laboratory, 2(11), 43-50.

Parkhomov, V. A. (2018). From Nerchinsk to Bargary (Fate of a son of an Ataman of the Third Military Unit of the Transbaikal Cossack Army and his family). Retrieved from Connected by Family Ties. Irkutsk, 87-115.

Parkhomov, V. A., \& Barottsi, E. V. (2011). Life Journey of a Transbaikal Cossack Army Ataman. Research Bulletin of the Baikal State University of Economics and Law, (9), 75-88.

Results of RSFSR Elections to Soviets 1929. - Edition 1. Rural, Volost, District Elections: Collected articles. (1930). Moscow: Soviet Rule Publishers under the All-Russian Central Executive Committee Presidium. 
Soviet Elections and Structure of USSR Government. (1931). Retrieved from https://archive.org/details/vybory_sovet_sostav_organov

Supreme Orders of the Military Department. (1915). Razvedchik Journal 1297, St. Petersburg.

Troitskosavsk Electoral Commission. List of Disenfranchised Former White Officers and Sellers. (1928). National Archive of Republic of Buryatia (NARB). FR-726, inventory 1, case No.163, in 24 sheets.

Valuev, D. B. (2003). Non-voters in the system of social relations (1918-1936) (based on data about the West Region of the RSFSR) (Dissertation for Ph.D. degree in History). Smolensk.

\section{Copyrights}

Copyright for this article is retained by the author(s), with first publication rights granted to the journal.

This is an open-access article distributed under the terms and conditions of the Creative Commons Attribution license (http://creativecommons.org/licenses/by/4.0/). 